Отримано: 17 грудня 2020 р.

Прорецензовано: 28 грудня 2020 р.

Прийнято до друку: 28 грудня 2020 р.

e-mail: by-ru@list.ru

DOI: $10.25264 / 2415-7384-2021-12-90-94$
Svilo Ya. V. Coping strategies as a personal resource in high adolescence. Наукові записки Національного університету «Острозька академія». Серія «Психологія» : науковий журнал. Острог : Вид-во НаУОА, січень 2021. № 12. С. 90-94.

\author{
Yanina V. Svilo, \\ post-graduate student of the Department of psychology \\ Gomel State University named after F. Skorina
}

\title{
COPING STRATEGIES AS A PERSONAL RESOURCE IN HIGH ADOLESCENCE
}

This article considers coping strategies as a resource for an individual in a difficult life or stressful situation. The article gives the definition of coping behavior. Situations are given that, according to the results of research by I. M. Nikolskaya and R. M. Granovskaya, are stressful for children and require the use of coping strategies to cope with them. Such situations are: loss, illness and death of an animal; low school performance; injuries and life-threatening situations; adult problems, including material ones; conflict situations in the family; loss of a loved one, his illness; other fears and stressful situations. These authors also are considering the main ways for children and adults to cope with stressful situations. Children are more inclined to use the following coping methods: active involvement in the resolution of the current situation (correction of the assessment, a step towards reconciliation with a friend); search for social support (search for people who can listen, understand, support, give advice); concentration on your own desires (satisfaction of what you really wanted for some time); abstraction from the situation, withdrawal; analyzing the situation and giving it a new meaning.

The features of coping strategies in childhood are emphasized. It is noted that coping strategies used by children develop in the family and depend on the coping behavior of parents or other significant people. The article is considering the researches of a number of authors devoted to the study of the dynamics of coping behavior of students from early childhood to adolescence. The difference in the preferred ways of coping with difficult situations, depending on the gender of the child in each age period, is emphasized.

This article presents the results of the study of coping strategies used by children of senior adolescence. In total, 54 schoolchildren, students of grades 9-11, took part in the study. The methodology "Strategies for overcoming stressful situations" (SACS) by S. Hobfoll, adapted by N. Vodopyanova and E. Starchenkova, was used as a diagnostic material. The questionnaire contains nine models of coping behavior: "Assertive actions", "Entering into social contact", "Search for social support", "Cautious actions", "Impulsive actions", "Avoidance”, "Indirect actions", "Asocial actions", "Aggressive actions".

Among high school students, high rates are noted on the scales of "avoidance", "asocial actions", "aggressive actions". The rest of the scales are dominated by average indicators. Accordingly, older students in stressful situations tend to react aggressively to problems, blame the people around them for what is happening, and also ignore the situation, behave as if nothing had happened, and avoid thinking about a problem situation. They put themselves above all others, they believe that only their opinion is correct.

By the study the general index of constructiveness of coping strategies, it is noted that the majority of the subjects have an average level of constructiveness, which indicates that, in general, they are able to cope with stressful situations without negative consequences in the future.

Key words: coping behavior, coping strategies, personality resources, constructiveness index.

\section{Свило Яніна Володимирівна,}

аспірантка кафедри психології

Гомельського державного університету імені Ф. Скорини

\section{КОПІНГ-СТРАТЕГІЇ ЯК РЕСУРС ОСОБИСТОСТІ В СТАРШОМУ ПІДЛІТКОВОМУ ВІЦІ}

У статті розглядаються копінг-стратегії як ресурс особистості у важкій життєвій або стресовій ситуаиії. Розглядаються визначення поняття “копінг-стратегії”. Вивчаються і аналізуються ситуації, які, за результатами дослідження I. М. Нікольської і Р. М. Грановської, є стресовими для дітей і вимагають використання копінгстратегій для для їх подолання. В якості таких ситуацій виступають: втрата, хвороба і смерть тварини; низька шкільна успішність; травми і небезпечні для життя ситуаиії; проблеми дорослих, в тому числі матеріальні; конфліктні ситуації в сім'ї; втрата близької людини, його хвороба; інші страхи і стресові ситуаџії. Дані автори також розглядають основні способи, за допомогою яких діти і дорослі долають стресові ситуації. Підкреслюються особливості стратегій для подолання стресових ситуацій в дитячому віці. Відзначається, щуо копінг-стратегї̈, використовувані дітьми розвиваються в сім'ї $і$ залежать від копінг-поведінки батьків або інших значущих $і$ близьких для дітей людей. Розглядаються дослідження ряду авторів, присвячені вивченню динаміки копінг-поведінки учнів 3 раннього дитячого віку до підліткового віку. Підкреслюються відмінність бажаних способів впоратися з важкими ситуаціями в залежності від статі дитини в кожен віковий період. Наводяться результати дослідження копінгстратегій, використовуваних дітьми старшого підліткового віку. Всього в дослідженні взяло участь 54 школярі, 
учні 9-11 класів. В якості діагностичного матеріалу була використана методика “Стратегії подолання стресових ситуачій” (SACS) с. Хобфолла, адаптована Н.Водоп'янової і Е. Старченкової. Серед учнів старших класів високі показники відзначаються за шкалами “уникнення”, “асоціальні діi”, “агресивні діi”,. За іншими шкалами переважають середні показники. Відповідно, старші школярі в стресових ситуаціях схильні агресивно реагувати на проблеми, звинувачувати в тому, щчо відбувається оточуючих людей, а також ігнорувати ситуацію, вести себе як ніби нічого не сталося, уникати думок про проблемну ситуацію. Досліджуючи загальний індекс конструктивності копінг-стратегій, наголошується, щуо у більшості досліджуваних середній рівень конструктивності, щцо свідчить про те, щзо в цілому вони здатні впоратися зі стресовими ситуаціями без негативних наслідків в майбутньому.

Ключові слова: копінг-поведінка, копінг-стратегії, ресурси особистості, індекс конструктивності.

Introduction. To overcome difficult life, stressful or tense situations that face a person, it is necessary to use the full potential of the individual, to actualize the abilities and skills that the person does not use in the usual conditions of his life. The mechanism for overcoming difficult life situations in psychological science is often defined as "coping behavior", the main function of which is adaptation to the requirements of the situation.

The study of coping strategies and coping behavior, in general, in modern psychology is one of the most pressing problems. The analysis of scientific literature on the research problem showed that coping behavior, is considered in modern psychology as an individual way of a person's interaction with a situation, according to its vital significance for him, a person's psychological capabilities to overcome it and the logic of the implementation of this process. In a broad sense, coping encompasses all types of interaction of the subject with tasks of an external or internal nature: attempts to master, get used to, soften or evade the requirements of a difficult life situation, manifested in special conditions of personality existence (stress, frustration, conflict and crisis) [1].

Theoretical analysis of the problem. Coping behavior is a kind of scenario that determines a stable way of mental adaptation, which can influence social attitudes and the nature of interpersonal relationships. Coping behavior can reduce the impact of a negative stressor, thereby performing a protective function. Coping strategies begin to form in childhood, in the process of interacting with others, primarily with parents [2]. Current research shows that children's coping behavior depends on their parents' coping behavior [3]. This is proof that coping behavior is formed in the process of child development, and, accordingly, this process is influenced by parents and other significant people. Thus, coping behavior must be considered as one of the socio-psychological resources. Resources are anything that a person can use to overcome a problem or stressful situation. Thus, it is necessary to identify situations that require children to use personal resources.

For example, Russian psychologists I. M. Nikolskaya and R. M. Granovskaya conducted a survey of children in their research and found that such situations are: loss, illness and death of an animal; low school performance; injuries and life-threatening situations; adult problems, including material ones; conflict situations in the family; loss of a loved one, his illness; other fears and stressful situations [4].

It is worth noting that these results were obtained on the basis of a survey of children themselves, so this list includes those situations that the children themselves wanted to share. Accordingly, it can be assumed that this list is not accurate and there may be more traumatic, stressful situations, but children for some reason (shame, fear, a promise not to tell anyone) do not want to talk about it.

Adults in stressful situations tend to behave in different ways. I. M. Nikolskaya and R. M. Granovskaya indicate that in such situations, adults often use the following coping mechanisms [5]:

1) They resort to creativity: they attend cultural events, read literature, listen to music, etc.

2) They look for social support.

3) They start working hard.

4) They use a change in the type of activity from mental activity to physical activity (physical work, sports, walking in the fresh air)

5) They start to eat a lot, sleep a lot, walk a lot. They avoid solving the problem.

6) They think over and comprehend the existing problem.

At the same time, children are more inclined to use the following coping methods [5]:

1) Active involvement in the resolution of the current situation (correction of the assessment, a step towards reconciliation with a friend).

2) Search for social support (search for people who can listen, understand, support, give advice).

3) Concentration on your own desires (satisfaction of what you really wanted for some time).

4) Abstraction from the situation, withdrawal.

5) Analyzing the situation and giving it a new meaning.

The authors emphasize the features of coping behavior of children, in contrast to adults. The indicators are more similar in the behavioral area. Strategies related to this area are successfully used by both adults and children. Moreover, their methods are different. Emotional strategies (crying, screaming, anger) are more often used by children [6]. In turn, strategies that relate to the intellectual sphere are more typical for adults, since children do not have enough opportunities for this [7]. 
In modern psychological literature, coping resources are considered as specific manifestations of coping behavior (emotional, behavioral, cognitive, personal, environmental, and others), which are united by one goal [8].

Silina O.V. in her research devoted to coping resources of children comes to the following conclusions. At the age of 2-3 years, coping strategies are primitive. Boys of this age are characterized by an attack strategy, girls - leaving, flight. For them, the most important resource of protection is a significant adult, a parent (adult) acts as a way to recuperate through conversation, consolation, hugs and others [9].

At the age of 4-5, boys' coping strategy consists in their personal life activity, stability, the desire to influence external sources, fearlessness, the word "obstacle" itself is absent from their worldview. Girls of this age begin to show "feminine" strategies of behavior, such as gentleness, kindness, responsiveness, fairness, compliance, etc. Thus, the main coping resource for children of this age group is the value of gender identity, awareness of their own gender identity.

At the age of 6-7, boys tend to use coping strategies for avoiding situations, detachment. At the same time, the main coping resource of girls is developed communication skills.

At the age of 8-10 years, significant changes are noted. Boys tend to use communication skills as coping resources, knowledge of social rules of behavior. The dominant coping resources for girls are the resources of the emotional sphere [10].

Smirnova M.V. in her work notes that children, starting from primary school age, are able to notice and understand the peculiarities of their coping behavior. But, at the same time, the possibilities of using strategies related to the intellectual sphere by children are limited. Accordingly, children often resort to using emotional methods of coping with stressful situations, since the manifestation of emotions is a habitual reaction of the child. Children from an early age actively engage and adapt to the changing environment around them. These experiences can be both positive and negative, and this contributes to the activation of defense mechanisms and coping strategies. The leading factor that can influence the formation of psychological defense and the formation of coping strategies is the family, the relationships in which largely determine the methods of coping behavior. Relations with peers and teachers also play an important role in primary school age [11]. S. I. Matafonova considers "the search for social support" as the most effective coping resource for younger students [12]. Social support can smooth out the negative impact of stressful events on the child's personality, while acting as an important resource.

A number of authors (T. L. Kryukova, M. V. Saporovskaya, A.V. Smirnova) have identified the family as the leading source of personal resources, since it is the "translator of social experience", and the mechanism of transmitting "translation" is the experience of child-parent relations, where the perception of social support is considered from the position of protection, which allows younger schoolchildren to come to the opinion that they are loved, valued, cared for, and that they are a family member [13], [14], [15].

Many psychological studies emphasize the leading role of the mother in building interaction with a child of primary school age [14]. The peculiarities of parent-child relations lie in the duality: 1) the attitude of the mother to the child, 2) the child's assessment of the parental attitude to himself. Naturally, there is a connection between these positions, but they are not equivalent. "At primary school age, these relationships are recognized by the child, they are objectified in emotions, feelings and experiences in the process of communicating with parents. The findings show that perceptions of social support reflect parent-child relationships. Assessment of these relations as "controlling" is the main socially supportive coping resource of primary schoolchildren" [12].

With the onset of adolescence, there is a decrease in the efficiency of coping resources functioning (low selfesteem, a high level of anxiety, a low level of empathy, motivation to avoid failures prevail), a predominance of unproductive and relatively productive coping strategies, a weak variability of cognitive, emotional and behavioral responses. Such coping resources and coping strategies of adolescents indicate the need for special psychological and pedagogical work aimed at the formation of protective coping resources and productive coping strategies of behavior, which is regarded by us as an increase in adaptive potential [16].

In modern psychological studies, there is a tendency to move from the study of deficiency to the study of resourcefulness. At the same time, adolescence is one of the most difficult age periods, since the personality of a teenager faces difficulties that may not be ready to cope with. Not all children of this age have sufficient resources for a prosperous movement from childhood to adulthood. Thus, the aim of the study is to identify the features of coping strategies of older adolescents.

Methods of research. The study examined the coping strategies of high adolescence (grades 9-11). The empirical base of the study consisted of 54 people studying in different schools. The sample consisted of male and female representatives. The methodology "Strategies for overcoming stressful situations" (SACS) by S. Hobfoll, adapted by N. Vodopyanova and E. Starchenkova, was used as a diagnostic material. The questionnaire contains nine models of coping behavior [17]: "Assertive actions", "Entering into social contact", "Search for social support", "Cautious actions", "Impulsive actions", "Avoidance", "Indirect actions", “Asocial actions", 
"Aggressive actions". Stress coping strategies can be: productive, allowing you to solve the problem, relatively productive, and unproductive.

Research results. At senior adolescence, according to the scale of "Assertive actions", the majority of students (61\%) have an average level, $17 \%$ have a high level, and $22 \%$ have a low level.

On the scale of "Entering into social contact", the majority of respondents (46\%) have an average level, 30\% have a high level, and $24 \%$ have a low level.

On the scale of "Search for social support", a larger number of students (43\%) also have an average level, $35 \%$ have a high level, and $22 \%$ have a low level.

On the scale of "Cautious actions", the majority (48\%) of the surveyed schoolchildren have the average level, $41 \%$ have a high level, only $11 \%$ of schoolchildren have a low level.

On the scale of "Impulsive actions", the majority of respondents (46\%) have an average level, $33 \%$ have a high level, and $21 \%$ have a low level.

On the scale of "Avoidance" the results were distributed as follows: a high level have 59\% of students, $33 \%$ - an average level, $8 \%$ - a low one.

On the scale of "Indirect actions", half (50\%) of the surveyed schoolchildren have an average level, $31 \%$ have a high level, and $19 \%$ of schoolchildren have a low level.

On the scale of "Antisocial actions", the majority of senior school students (52\%) have a high level, $44 \%$ of students have an average level and only $4 \%$ have a low level.

On the scale of "Aggressive actions", the overwhelming majority (70\%) of the respondents have a high level, $21 \%$ have an average level and only $9 \%$ have a low level.

The data on the scales are presented in the form of a diagram in picture 1.

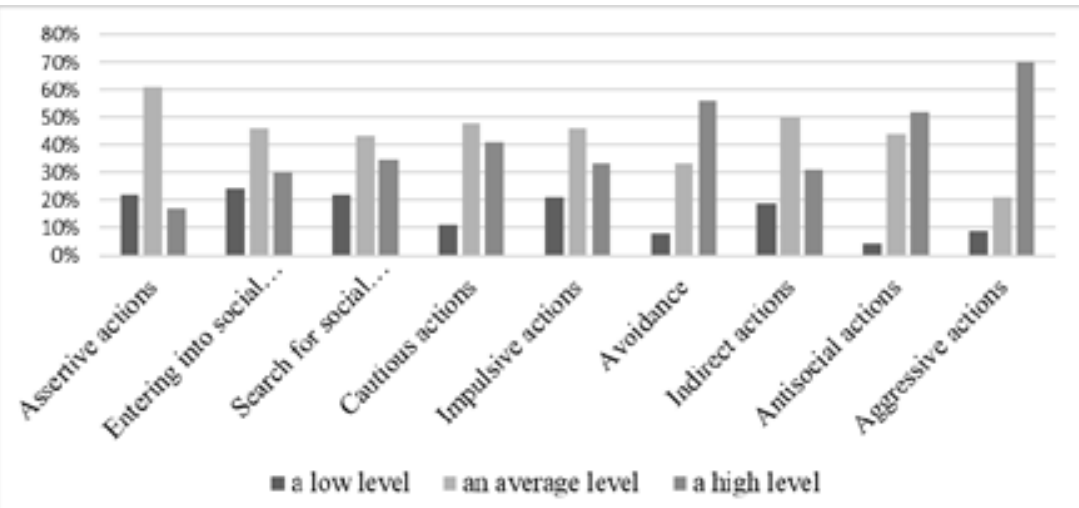

Pic. 1 - distribution of data by scale

Analyzing the index of constructiveness, we note that half of the students $(50 \%)$ have an average level of constructiveness, $44 \%$ have a high level, and $6 \%$ have a low level of constructiveness. These results indicate that senior adolescence more often use constructive coping strategies, respond appropriately to the stress situation that has arisen, and also smooth out possible negative consequences.

Conclusion. Thus, among high adolescence high rates are noted on the scales of "avoidance", "asocial actions", "aggressive actions". This indicates that in a problem situation students tend to show aggressive actions, negatively interpret the behavior of people around them. They walk away from the problem, ignore troubles, behave as if nothing happened, switch to other things and events. However, they are prone to illegal actions, hostility. They put themselves above all others, they believe that only their opinion is correct. Students of this age group tend to use productive coping strategies more often, so they overcome stressful situations faster and with less consequences.

\section{References:}

1. Нартова-Бочавер С. К. «Сoping behavior» в системе понятий психологии личности. Психологический журнал. М., 1997. № 5. С. 20-30.

2. Михайлова Н. Ф., Смирнова А. В. Формирование совладающего поведения у детей. Российский психологический журнал. 2006. № 3. URL: https://cyberleninka.ru/article/n/formirovanie-sovladayuschego-povedeniyau-detey (дата обращения: 10.11.2020).

3. Михайлова Н.Ф., Машталь О.Ю., Сорокина А. В. Влияние копинг-стиля родителей на формирование механизмов совладания у детей. Материалы научно-практич. конф.: Ананьевские чтения - 2004 (Юбилей кафедры медицинской психологии и психофизиологии). Санкт-Петербургский университет, 2003. С. 417-420.

4. Никольская И. М., Грановская Р. М. Психологическая защита у детей. СПб.: Речь, 2000. 507 с.

5. Грановская Р. М., Никольская И. М. Защита личности: психологические механизмы. СПб.: Знание, 1999. $352 \mathrm{c}$.

Наукові записки Національного університету «Острозька академія», серія «Психологія», № 12, січень, 2021 р. 
6. Лебединский В. В. Нарушения психического развития в детском возрасте: Учеб. пособие для студ. психол. фак. высш. учеб. заведений. М.: Издательский центр «Академия», 2003. 144 с.

7. Деглин В. Л. Парадоксальные стороны человеческого мышления: Нейропсихологический анализ. СПб., 1996. $36 \mathrm{c}$.

8. Куфтяк Е. В. Факторы становления совладающего поведения в детском и подростковом возрасте. Психологические исследования. 2012. №. 2(22). C. 4. URL: http://psystudy.ru. (дата обращения: 01.11.2020).

9. Силина О. В. Формирование системы копинг-ресурсов у детей 2-10 лет с позиции теории психологических границ личности. Психология стресса и совладающего поведения: ресурсы, здоровье, развитие: материалы IV Междунар. науч. конф.: в 2-х томах, 2016. С. 254-256.

10. Нартова-Бочавер С. К., Силина О. В. Динамика развития психологических границ на протяжении детства. Актуальные проблемы психологического знания. 2014. Т. 32, № 3. С. 13-28.

11. Смирнова М. В. Копинг-стратегии у детей младшего школьного возраста. Системная психология и социология. 2012. № 6 (2). С. 103-111.

12. Матафонова С. И. Поиск социальной поддержки как эффективный копинг-ресурс психологического здоровья младших школьников. В мире научных открытий. Социально-гуманитарные науки. Красноярск: Изд-во Научно-Инновационный Центр, 2014. № 11, 7 (59). С. 2483-2494.

13. Крюкова Т. Л. Психология совладающего поведения: монография. Кострома: «Авантитул», 2004. 344 с.

14. Сапоровская М. В. Родители и дети: к вопросу о детерминантах детско-родительских отношений. Психология и практика. Кострома: Изд-во КГУ им. Н.А. Некрасова, 2001. С. 73-85.

15. Смирнова А. В., Михайлова Н. Ф. Формирование совладающего поведения у детей. Российский психологический журнал. 2006. Т. 3. № 2. С. 38-51.

16. Симатова О. Б. Копинг-ресурсы и копинг-стратегии как показатели адаптационного потенциала подростков. Akademicka Psychologie. 2016. № 1. Р. 50-57.

17. Водопьянова Н. Е., Старченкова Е.С. Стратегии и модели преодолевающего поведения. Практикум по психологии менеджмента и профессиональной деятельности. СПб.: Изд-во «Речь», 2001. С. 311-321. 